\title{
Level Literacy of Information Technology Millennial Generation: A Case Study at Student Universitas Negeri Padang
}

\author{
Marlini, Elva Rahmah, Desriyeni \\ FBS, Universitas Negeri Padang \\ marlini.unp@gmail.com
}

\begin{abstract}
Universitas Negeri Padang becomes a barometer in the development of information and communication technology (ICT) for the realization of the present generation. Universitas Negeri Padang has declared as a Cyber campus whose goal is to educate students to be technologically literate. Therefore it is necessary to do research on the level of technological literacy of students at Universitas Negeri Padang. This research used survey method with sampling probability / random sampling technique and stratified random sampling technique. The results revealed that the level of technological literacy in the students of Universitas Negeri Padang can be categorized quite good / high. Of the three media technology researched Smartphone is the most widely used media then computers and the internet. The purpose of using this technology is to make it easier to communicate, complete tasks and obtain information. These results will greatly help the process of making the success of the Universitas Negeri Padang program that makes the cyber campus.
\end{abstract}

Keywords--Literacy Technology, Computers, Internet, Smartphone

\section{INTRODUCTION}

Millennial generation is a term for generations born in the 1980s through 2000 and is familiar (fluent) with digital technology. Both of these are interrelated given the ever-expanding technology, and closely with everyday human life. So as users of these devices, we are also required to be literate to the world of technology. Literate in the sense of understanding, evaluating and making things (can be a producer, not just a consumer). Literacy technology is a set of capabilities that must be owned by someone in using technology tools such as the Internet that involves technical skills and cognitive intelligence.

Meanwhile, there is now a transition from the educational system of the old and the present. This must be done in order to adjust to the millennial generation so as not to lag. For example is the education system in college. The teaching system in college is no longer a one-way, but more two-way, competitive, multidisciplinary, and high productivity. Discussion methods should be more portions so as to follow the development of technology.

Abroad has already been taught in the cafeteria or coffee shop. Classes with multiday teaching methods like this will enhance the culture of research and entrepreneurship. Globalization and the era of digitalization are the triggers of a shift in education. Therefore, it should really be utilized as an opportunity to continuously improve the quality of education. Not only that, the rapid use of technology in education makes the choice of learning resources available such as e-books (e-books), easy access of digital applications such as e -library and e-journal.

According to the Maryland Technology Education State Curriculum, technology literacy is the ability to use, understand, organize and appraise an innovation involving processes and knowledge to solve problems and expand one's capabilities.

According to the National Academy of Engineering and National Research Council of the National Academic of technological literacy is an understanding of technology at a level that enables effective utilization in modern technological society consisting of three main components of knowledge, ability and critical thinking, and decisionmaking.

The present generation or millennial generation has taken advantage of technological advances to interact with others. This generation is considered very fast to adopt technological developments. Example of technology that is used today is a cell phones something that cannot be separated to search. Needs work, communication, create a new status to exist in social media, shopping until looking for a partner all are in the grip.

Currently with the touch of the third technology resulted in the development of mobile devices is so rapid. Various prices of mobile devices and internet connection costs are also increasingly decreased and can be reached by all walks of life. In addition, information services can be accessed from mobile devices, either with direct access or application programs on mobile devices.

In http://mlibraries.jiscinvolve.org/wp/ mentioned about the survey to show the level of confidence in using mobile technology. The level of trust is measured from: Very Confident, Confident, Not Confident, and Very Confident as in Figure 1 below: 


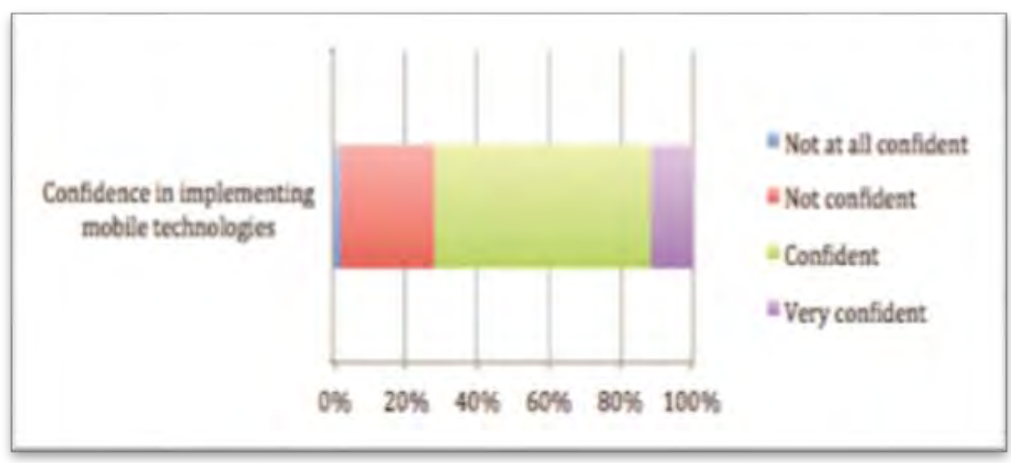

Figure 1. Level Of Trust In Implementing Mobile Technology

From the exposure of the above concepts, the concept framework in this study to be able to measure the level of technological literacy (computer, internet and smartphone) students, then the indicators that must be seen is if he is able to utilize the technology, frequency, time and location of technology use as well as the purpose of using technology in this regard to make lecturing assignments, access data and information, have fun and communicate. From here it can be concluded how far the level of student technology literacy.

\section{METHODS}

This research is conducted by survey method that aims to collect and dig a large amount of data for further analysis. Population in this research is student of State University of Padang. While the sampling conducted is no probability that is not all populations have a chance to become respondents. which with the total population of 230 , researchers only take samples as much as $40 \%$ of the total population of 92 respondents. The respondents consist of students of IPK study program from class of 2016 to 2018, where each force is divided into two local namely local A and local B the total number is 6 local. The distribution of questionnaires to 92 students IPK study then returned to researchers with the same number, i.e. 92 questionnaires $(100 \%)$.

\section{A. Literacy Level of Student Technology State University of Padang}

\section{FINDING AND DISCUSSION}

\section{Computer}

Based on the data of research results, students who can use the computer as much as 92 students or $100 \%$, Thus the entire student can use the computer. In general, students use computers at home or in House for rent, and campus. In graph 1 below is a description of the purpose of computer use by students. From the results of the study said that the majority of students are $90 \%$ using computers to manage words, data and numbers or in other words they use computers to complete the task and have fun in this case watching on YouTube to be the most activity. followed by a second facebook utilized by $90 \%$ of students. This means in addition to completing the task and work, computer as well as a medium that can entertain users is to play various games that are installed on each computer.

\section{Graph 1}

Level of Use of Computer Applications

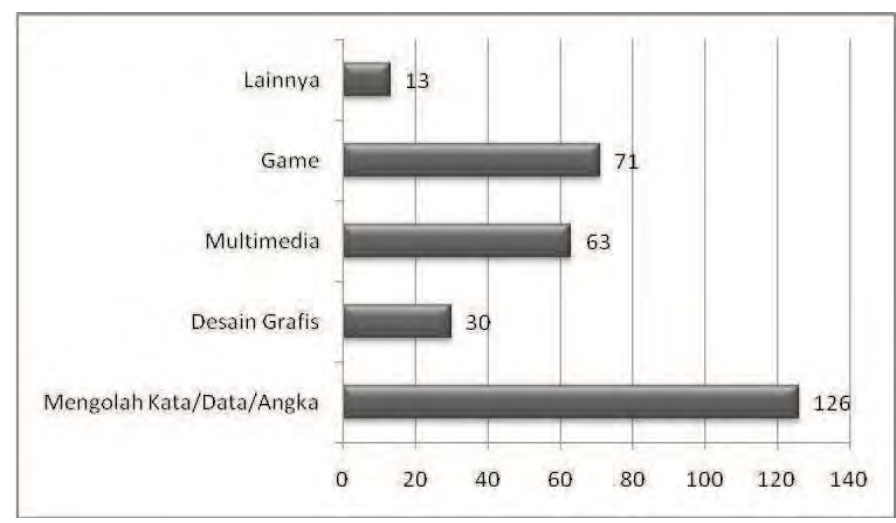

Source: primary data processed

Based on the data in graph 2 it can be seen that for the use of standalone application programs such as office applications, multimedia applications and games or games are understood, used and used by the students, this is because 
this application is a standard application on every computer. While the most widely used program is Windows as much as $68.8 \%$ of students, and open source as much as $5.4 \%$ of students. The results also showed that as many as $37.6 \%$ of students stated that computers really help the work they do. This means that this computer media has become the main tool of students in helping to complete the work.

Graph 2

Level of Use of Computer

\section{Internet}

For internet use, the results showed that most of the students (100\%) said they could use the internet. This shows that student interest and student internet usage rate is high. And most of the students replied that they were almost as thin as the day using the internet. Most students also spend about 2-4 hours a day while using the internet. While the use of the internet to learn, the average time that students use to learn a lot ranges $2-4$ hours. And as many as $31.7 \%$ of students answered the internet is very helpful in their learning process. And the average student spends the internet cost in a month is 50-100 thousand rupiah. Generally students use the internet at home or in kosan, on campus and free wifi in public areas, also a choice of students when using internet access. So this makes it easier for students to access the internet anywhere.

Graph 3.

Activities While Using the Internet

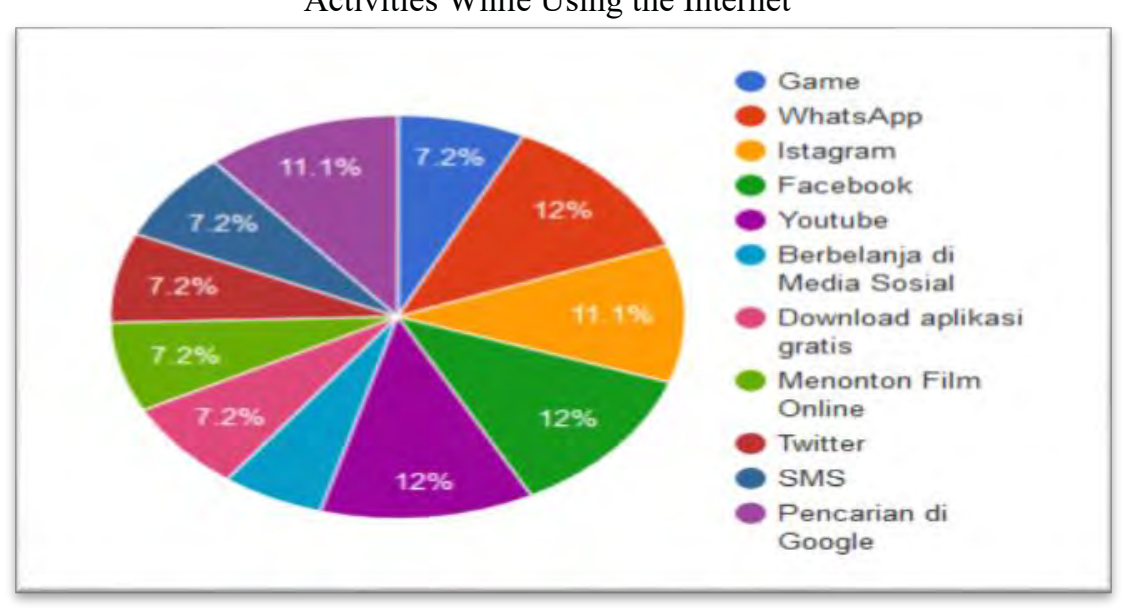

Source: primary data processed

The activities that students do when using the internet the most is to open and send messages via WatsApp, access data and information through Google, social networking, data downloading, chatting, and so forth. It can be seen that communicating through WatsApp is a top choice for students. Due to the fast access and can be done anywhere. Even through Smartphone's that have been equipped with internet access though, students can directly send a message to someone. In addition, the student's need for any information has become a major requirement for students. This appears to take their activities while accessing the internet is looking for information. This means that student technology literacy is very adequate. While the social networking site which is the most activity accessed by students via the internet can be concluded that students with awareness of ICT literacy, really need to be able to communicate 
with many people with different medium through the internet.

\section{Smartphone}

If a few years ago komting students provide information to their friends using the communication network (jarkom) SMS, but now has shifted after the presence of more sophisticated facilities through the Smartphone (eg WatsApp, BBM and Twitter). The fact that there is a number of Smartphone already exceeded the population of Indonesia.

Asia's technology media in one of its articles referred to Indonesia as "Southeast Asia's technological giant sleeping." But from the data available, Indonesia is actually likely to be one of the biggest not only in Southeast Asia but also Asia. Its population reaches 250 million, and it becomes a big market. Indonesian Smartphone users are also growing rapidly. Digital marketing research institute Emarketer estimates that by 2018 the number of active Smartphone users in Indonesia will reach more than 100 million people. With that amount, Indonesia will be the country with the fourth largest Smartphone active users in the world after China, India, and America.

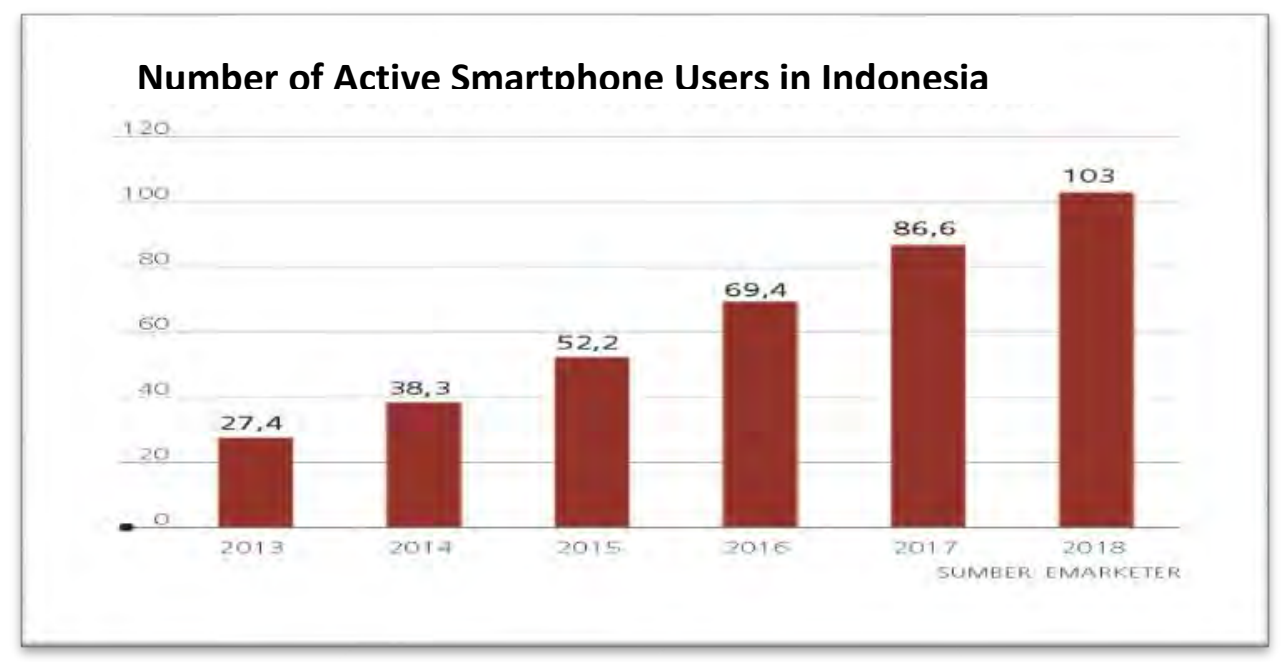

Source: https://www.emarketer.com

For Smartphone use research data shows that the majority of students or $93.7 \%$ have Smartphone. Even $39.8 \%$ among students who have more than 1 Smartphone. This means that Smartphone media is no longer an exclusive and expensive media. With the increasing number of brand choices and various facilities offered plus the price of pulses among competing Smartphone providers offer the cheapest price for students to make this media more and more owned by students. Not to mention the needs of students for information and communication that make students have more than one Smartphone media.

\section{CONCLUSION AND RECOMMENDATION}

The level of student technology literacy can be categorized quite good / high, because based on the three media technology examined the computer, internet and Smartphone all have been utilized by students.

The level of computer literacy by students is quite high. Utilization of this medium an average of 5 times a week or 5 days a week for 2-4 hours / day and most students use their own home computer and in house for rent. Students aim to use the computer to process words, data and numbers or in other words to complete the task. So from here also can be seen that the Windows application program into a standard program used by the majority of students.

While the level of student internet literacy can also be said quite high, students who use it at home and campus with average usage rate every day for 2-4 hours / day. The activities are widely used by students is to send messages, access data and information and social networking. The benefits of the internet is also greatly felt by students that is easier to get information, facilitate communication and help speed up the work

For Smartphone literacy can be said to be very high. Because this media is the most technology owned by students. This indicates that the need for communication is also greater. In addition, the Smartphone is not only used as a tool to communicate but also to access data and information considering the Smartphone already offers various applications and features to access the internet.

From the above conclusions, it is suggested that Universitas Negeri Padang should cooperate with private parties and communities to further develop the information technology infrastructure of campus communication to make it easier for students to use ICT facilities. Universities can build and grow wife, media centers and the like to provide the 
widest possible opportunity for students to use computers and internet facilities widely and quickly. Subsequent research is more focused on the level of social media literacy generation now case study at State University's students.

\section{References}

End of Project Survey - "Confidence in Implementing Mobile Technologies" In http://mlibraries.jiscinvolve.org/ $\mathrm{wp} /[$ access 2 July 2018]

Judy and Donna (2005). Intergrating instruction literacy and science. New York London:The Guilford Press Jumlah Pengguna Aktif Smartphone di Indonesia. In https://www.emarketer.com. [access 9 July 2018]

Jumlah Ponsel Lampaui Penduduk. In http://teknologi.kompasiana.com/gadg- et/2012/02/21/jumlah ponsellampaui penduduk/ [access 2 July 2018]

Maryland State Department of Education. 2005. Maryland technology education state curriculum. Baltimore, Maryland.

Mobile Technologies in Libraries: Supporting Libraries in the use and development of mobile technologies. http://mlibraries.jiscinvolve.org/wp

National Academy of Engineering and National Research Council. 2006. Tech Tally: Approaches to

Assessing Technological Literacy. Washington, DC: The National Academies Press.

Susan and Carolyn (2007). Intergrating Literacy and Technology.New York London:The Guilford Press

What is M-Libraries. In http://mlibraries.jiscinvolve.org/wp/2018/6/10/what-is-m-libraries/ [access 1 July 2018]

What Happens In The Virtual World For 60 Seconds. In https://www.allaccess.com. [access 9 July 2018] 